\title{
LIFE COURSE FACTORS ASSOCIATED WITH WASTING IN CHILDREN UNDER FIVE IN EAST LOMBOK, WEST NUSA TENGGARA
}

\author{
Husniyati Sajalia'), Yulia Lanti Retno Dewi²), Bhisma Murti1) \\ 1)Masters Program in Public Health, Universitas Sebelas Maret \\ ${ }^{2)}$ Faculty of Medicine, Universitas Sebelas Maret
}

\begin{abstract}
Background:Wasting, stunting, and underweight are the most devastating problems affecting the majority of the world's children. Worldwide, 52 million children under five years of age are wasted and most of the global burden of wasting (acute undernutrition) is found in developing countries. That poor nutritional status during childhood has long-lasting scarring consequences. Undernutrition diminishes the working capacity of an individual during adulthood, and it silently destroys the future socio-economic development of nations. This study aimed to investigate life course factors associated with wasting in children under five in East Lombok, West Nusa Tenggara, Indonesia.

Subjects and Method: This was a case control study carried out at 31 posyandus (integrated family health post), East Lombok, West Nusa Tenggara, Indonesia, from April to May 2018. A sample of 186 children under five was selected by fixed disease sampling consisting of 62 wasted children and 124 normal children. The dependent variable was wasting. The independent variables were maternal age at pregnancy, maternal middle upper arm circumference (MUAC), low birthweight, exclusive breastfeeding, history of infectious disease, and family income. The data were collected by questionnaire and analyzed by a level logistic regression.

Results: The risk of wasting decreased with high family income $(b=-1.49 ; 95 \%$ $\left.\mathrm{CI}=-3.13^{\text {to-0.15}} ; \mathrm{p}=0.075\right)$, maternal gestational $\mathrm{MUAC} \geq 23.5(\mathrm{~b}=-3.42 ; 95 \%$ $\mathrm{CI}=-5.97$ to $-0.83 ; \mathrm{p}=0.009)$, exclusive breastfeeding $(\mathrm{b}=-2.71 ; 95 \% \mathrm{CI}=-4.55$ to $-0.88 ; \mathrm{p}=0.004)$. The risk of wasting increased with maternal age at pregnancy $<20$ or $>35$ years $(b=1.57 ; 95 \% \mathrm{CI}=-0.21$ to $3.35 ; \mathrm{p}=0.084)$, low birthweight $(\mathrm{b}=$ 3.11; 95\% CI=-0.04to6.25; $\mathrm{p}=0.053)$ and infectious disease $(\mathrm{b}=3.36 ; 95 \% \mathrm{CI}=$ 1.41to5.26; $\mathrm{p}=0.001)$. ICC at Posyandu level $=8.82 \%$.

Conclusion:The risk of wasting decreases with high family income, maternal age at pregnancy $<20$ or $>35$ years, maternal gestational MUAC, exclusive breastfeeding, but it increases with low birthweight and infectious disease. Posyandu has a considerable effect on the risk of wasting.
\end{abstract}

Keywords:life course factors, wasting, multilevel analysis

\section{Correspondence:}

Husniyati Sajalia. Masters Program in Public Health, Universitas Sebelas Maret, Jl. Ir. Sutami No. 36 A, Surakarta, Central Java. Email: sajalia@gmail.com.

Mobile: +6281997987081. 